\title{
The Impact of Self -Affirmation Towards Stress and Anxiety Levels of Pregnant Women
}

\author{
Runjati Runjati $^{1 *}$, Annisa Septy Nurcahyani ${ }^{2}$
}

\author{
${ }^{1,2}$ Poltekkes Kemenkes Semarang \\ *Corresponding author. Email: runjati@yahoo.com
}

\begin{abstract}
Stress and anxiety during pregnancy has an impact on the risk of pregnancy, baby and birth. There is a need holistic care to cope with psychological adaptation during pregnancy. Self-affirmation by love card and deep breathing sounds to be part of holistic care but none of the study. This research aims are to find out the impact of holistic care on stress and anxiety levels of pregnant women at birth. This study was an experiment with a randomized pretest-posttest with control group design. The inclusion criteria in this study were pregnant women in the Public Health Center that was chosen through cluster and then simple random sampling, 40 respondents with 28-36 weeks aged pregnancy. The intervention group was treated with self-affirmation by love card with deep breathing within 2 weeks for 4 meetings besides antenatal education as part of standard antenatal care. The control group was given antenatal education only. The data was collected before, after the intervention, and at birth. The instrument of the research used DASS to measure stress and anxiety questionnaire. The data were analyzed by using GLM with post hoc LSD with the significantly less than 0.05 . The study revealed that there was an impact of self-affirmation by love card with deep breathing toward stress and anxiety before and after treatment and at birth with a p-value $<0.05$ significantly. Self-affirmations can be suggested to be an alternative to holistic care in the class of pregnant women to improve better outcomes during pregnancy and at birth.
\end{abstract}

Keywords: Self-affirmation, Love Card, Stress, Anxiety.

\section{INTRODUCTION}

During pregnancy, pregnant women experience not only physiological changes but also psychological changes due to an imbalance of the hormones estrogen and progesterone, causing pregnancy discomforts such as mood changes or increased anxiety, fear, and panic which can stress the mother [1]. Besides, there is also a mother's concern about her condition, such as fear of miscarriage, fear of inappropriate fetal development, fear of childbirth, fear of not being able to give birth normally, too often hearing about other people's negative experiences during childbirth, fear of pain and pain during childbirth will also cause stress and anxiety [1][2]. Some factors that influence the stress of pregnant women are an excessive worry, having negative thoughts about themselves, for example being physically different from before being pregnant, feeling worse than other pregnant women, worrying about not being able to care for the baby properly and having negative records because they often hear stories frightening or terrifying from others regarding labor [1][3].

Stress is a condition where the body's response is not specific to anything [4]. Stress affects a person's psychology and affects the nervous, endocrine, and immune systems [5]. The incidence of stress in pregnancy worldwide ranges from $14-54 \%$. India has a high prevalence of stress for pregnant women, amounting to $90-94 \%$ [6] and in Indonesia alone, the stress rate for pregnant women is at $55.6 \%$ [7] . 
Although the condition of psychological changes is due to hormonal changes, the psychological health condition of the mother during pregnancy is aggravated by anxiety and stress, which adversely affects pregnancy and continues to the outcome of labor. Stress and anxiety that occur during childhood affect the baby, depression during the puerperium, and increase high blood pressure [8][9]. In addition, based on the studies, it was obtained $63.2 \%$ of pregnant women who were stressed experienced severe insomnia during pregnancy [10]. Low birth weight, abnormal fetal brain development, autism, and schizophrenia are other effects of stress on pregnant women on the baby [8][9][11].

Treatment of psychological health problems during pregnancy is needed with nonpharmacological treatment. A holistic approach to care is a safe alternative for the health of both mother and fetus. The pregnant women will feel relaxed and comfortable, free from tension and anxiety if they can master the relaxation of their breath and instill positive sentences to themselves regularly and consistently. When relaxed, the body will release serotonin and endorphins, so that all nerves work in harmony and balance [12].

Furthermore, the psychological condition of pregnant women with stress and anxiety about pregnancy requires self-strengthening or positive self-affirmation because stress and anxiety originate from the mother's thoughts on the possible conditions of pregnancy and childbirth as well as environmental conditions and the mother's internal factors. Positive affirmations are sentences that are structured to convey to the subconscious mind to help in reprogramming negative thoughts into positive ones [13]. Positive affirmations are selfreinforcing or affirming to get rid of negative beliefs that exist in the subconscious mind [14]. Positive affirmations can only be limited to thoughts, written in a note, heard from others, or spoken to others in a way that is repeated to provide strength and confidence from within an individual [15]. Positive affirmations prepared for pregnant women have messages on physical and mental health, which play a role in motivating, inspiring, providing support, changing perspectives, influencing the body, soul, and mind to become habits of daily behavior [16].
Positive affirmations are sentences that are structured to be said to ourselves or to be heard from others and then spoken to ourselves [17]. The basis of affirmation is prayer, which can be interpreted as a more detailed and clear affirmation or reinforcement. Positive affirmations contain positive sentences that can influence the subconscious mind to form a positive mindset [18].

The written affirmation must be effective, use simple language, easy to understand, and specific because the subconscious can only accept positive words [19]. Positive affirmations can help reprogram a pregnant woman's subconscious tapes containing negative tapes into positive ones. In doing affirmations, the choice of words and language structures must be arranged following existing provisions, because if the language structure is wrong, it can endanger pregnant women and have a long and deep impact on the mother [3] [19][20][21].

Pregnant women with a relaxed and comfortable state are the best times to be given positive affirmations, one way to achieve a calm, comfortable, and focused state, namely doing abdominal breathing, inhaling from the nose, exhaling through the nose, when inhaling the stomach expands, exhaling the stomach deflating, do this several times until the muscle tension relaxes and the muscles are relaxed and comfortable [22][23].

During pregnancy, the mother gets standard care as a program from the government, namely through classes for pregnant women. The class for pregnant women is one of the programs that have been given by the government to empower pregnant women to have knowledge related to healthy pregnancy, safe and comfortable delivery, prevent various complications of pregnancy, childbirth, postpartum, care for newborns and increase the physical activities of pregnant women such as sports and labor breathing exercises [24]. Meanwhile, the existing class of pregnant women emphasizes the delivery of aspects of knowledge and skills during pregnancy, childbirth and the care of newborns. Comprehensive care is needed, not only in the aspects of knowledge and skills, especially during pregnant mothers are prone to experience stress and anxiety. An alternative to comprehensive care as a 
form of holistic care is to see the mother as a whole, not only in terms of body, mind but also the soul.

In the mother's class, breathing techniques are also taught, one of which is needed in breathing exercises that are integrated into the mother's class is abdominal breathing. Abdominal breathing is a form of care that teaches pregnant women to take deep, deep breaths and exhale slowly [25]. Abdominal breathing maximizes the oxygen entering the lungs and maximizes the dirty air and toxins out of the lungs. When breathing deeply and regularly, the breathing will turn slower so that the pulse and heart rate also decreases [23]. Abdominal breathing is one method that can be used when contractions come, this technique saves energy during the opening phase, provides deeper comfort, keeps the body supple and limp [26]. Besides, abdominal breathing can increase gas exchange, increase ventilation of the alveoli, reduce stress both physically and emotionally which can help reduce pain and anxiety [25].

Based on the literature review, care must be emphasized on aspects of self-strengthening or self-affirmation to reduce stress and anxiety and also equip mothers with the ability to manage stress and anxiety due to negative thoughts. Meanwhile, no research integrates the class of pregnant women with self-affirmation techniques and abdominal breathing. So, we need a study that combines the class of pregnant women as a standard of care set by the government by developing the need for positive affirmations with belly breathing of pregnant women to reduce stress and anxiety levels during pregnancy.

\section{METHODS}

The type of research used in this research is a quasi-experiment with a randomized pretestposttest design with control group design. This study is aimed to determine the effect of positive affirmations with abdominal breathing techniques on stress levels and anxiety of pregnant women during childbirth.

The population in this study were all threetrimester primigravida pregnant women who were in the working area of Puskesmas Kalimanah, Puskesmas Padamara, and Puskesmas Purbalingga, Purbalingga Regency, selected by cluster random sampling and simple random to determine the experimental group and the control group.

The inclusion criteria in this study were pregnant women aged 20-35 years, pregnant women with gestational age 28-36 weeks, and mothers without a history of disease, complications, and complications in pregnancy. The number of pregnant women sampled in each group was 20 pregnant women and randomly selected to participate in the pregnant women class.

This study used a Love card intervention containing positive affirmations ranging from breathing techniques, pregnancy, and childbirth to breastfeeding. Love cards are arranged and assembled with the aim of pregnant women being able to make positive affirmations with the correct sentence structure into the subconscious mind. Positive affirmation with the breathing technique using the abdominal muscles is carried out for 10 minutes per face to face in four meetings, which are integrated into the class of pregnant women. Pregnant women are given love cards containing positive affirmations that are trained outside the classroom by asking the mother to practice alone once a day between waking up, before going to bed, or when relaxing. Giving positive sentences to suggest themselves with love card media. Affirmation is done by repeating the words on the love card. The suggestions are implanted using simple language, easy to understand, in detail, and clear. For example, "From now onwards I'm getting calmer about pregnancy and preparation for childbirth."

Love cards were developed through literature studies and expert tests containing positive affirmations for pregnancy and childbirth. Love Card is a card designed to contain positive affirmations to help pregnant women do daily affirmations. Media cards with various images and colors create a fun and self-confident atmosphere [27]. The sentence structure in the love card is arranged according to the procedure for making affirmations so that the program that is inserted into the subconscious mind of pregnant women is correct and not harmful.

The instrument used in this study was a questionnaire sheet for the characteristics of the respondents to determine the characteristics of the respondents which contained data on name, address, education, occupation, gestational age, the 
first day of last menstruation and estimated day of birth. The control group only received a mother education class. By giving the same material to the class material for pregnant women by giving the same for 4 meetings according to the material in the class of pregnant women. With a duration of 20 minutes per face-to-face class for 4 pregnant women and the control group was given antenatal education only or IEC (Information and Education Communication). The difference in treatment was seen from the stress level and anxiety level before and after treatment.

Measurment of stress levels using the Depression Anxiety Stress Scale (DASS 42) questionnaire. DASS 42 consists of 42 question items covering three sub-variables, namely physical, emotional, and behavioral. Based on Cronbach's Alpha DASS 42 has a validity and reliability value of 0.91 . The stress categories on DASS 42 are divided into five categories, namely normal, mild, moderate, severe, and very heavy. Measuring the level of anxiety using a questionnaire Anxiety is the feeling that a person experiences when he thinks that something unpleasant will happen, for no apparent reason, is subjective, accompanied by physiological responses such as increased heart rate or muscle tension, and psychological responses such as being unable to focus attention. Anxiety in facing childbirth in this study was revealed by a modified scale of anxiety facing childbirth based on aspects consisting of physiological aspects and psychological aspects. The condition of the assessment is that the higher answer score obtained means the higher anxiety and the lower answer score obtained means the lower his anxiety is. The anxiety instrument was tested for validity and reliability with the value of validity with the validity coefficient (RBT) ranging from 0.366 to 0.764 with $p<0.05$ [28]. The measurements in this study were carried out three times, first before the intervention, second measurement at week 4 after the intervention, and measurement three times when the mother was facing labor.

EC or Ethical Clearance is a written statement of ethical feasibility and is given by the Research Ethics Commission which states that the research to be carried out meets the requirements to be carried out on living things. EthicalClearance in this study was issued by the Ethical Commission of the Sultan Agung Islamic University Semarang No. 008 / I / 2020 / Ethics Commission.

\section{RESULT}

\subsection{Characteristic of Pregnant Women}

The characteristics of the mother are shown in table 1 . It tested the difference between the two groups using the Mann-Whitney $U$ test obtained a value $\mathrm{p}>0.05$ in age, parity (number of children), education, occupation, and family support.

Based on the aforesaid statistics, we conclude that there is no difference in age, gestational age, support, employment, and education in the two groups. Also, the data characteristics of the respondents in the two groups are homogeneous.

Table 1. Characteristics of mother

\begin{tabular}{|c|c|c|c|}
\hline & $\begin{array}{l}\text { Afffirmation } \\
(\mathrm{N}=20)\end{array}$ & $\mathrm{AE}(\mathrm{N}=20)$ & \\
\hline $\begin{array}{l}\text { Characteris } \\
\text { tics }\end{array}$ & $\begin{array}{c}\text { Median } \\
(\min -\max ) \\
\mathrm{n}(\%)\end{array}$ & $\begin{array}{c}\text { Median } \\
(\min -\max ) \\
\mathrm{n}(\%)\end{array}$ & $p$ \\
\hline Age & $27(20-36)$ & $29(20-37)$ & $0.542 *$ \\
\hline $20-25$ & $6(30)$ & $5(25)$ & \\
\hline $26-30$ & $9(45)$ & $9(45)$ & \\
\hline $31-35$ & $5(25)$ & $6(30)$ & \\
\hline Parity & & & $1.000 *$ \\
\hline Primi & $10(50)$ & $8(40)$ & \\
\hline Multi & $10(50)$ & $12(60)$ & \\
\hline Education & & & $0.389 *$ \\
\hline \begin{tabular}{|l|} 
Primary \\
\end{tabular} & $1(5)$ & $0(0)$ & \\
\hline Secondary & $4(20)$ & $8(40)$ & \\
\hline Tertiary & $15(75)$ & $12(60)$ & \\
\hline $\begin{array}{l}\text { Occupati } \\
\text { on } \\
\end{array}$ & & & $0.202 *$ \\
\hline $\begin{array}{l}\text { Housewif } \\
\mathrm{e}\end{array}$ & $14(70)$ & $10(50)$ & \\
\hline \begin{tabular}{|l|} 
Private \\
\end{tabular} & $6(30)$ & $10(50)$ & \\
\hline \begin{tabular}{|l} 
Support \\
\end{tabular} & $9(7-10)$ & $9(7-10)$ & $0.933 *$ \\
\hline
\end{tabular}




\subsection{Proving The Effect of Positive Affirmation Class On Stress Levels of Pregnant Women During Childbirth}

The results are shown in Table 2 and Figure 1 shows that the experimental group who received the affirmation class experienced a sharper decrease in the mean stress score $(-4.36)$ on the second measurement after 4 weeks of intervention compared to the control group who received the education class. In contrast, the control group experienced an increase in the mean stress score (1.36), as well as the third measurement at delivery in the experimental group decreased $(-2.30)$, while the control group experienced a slight decrease with an average stress score (-0.55). ).

In the experimental group, the stress score difference test before and after the positive affirmation intervention at the second measurement of the fourth week after the intervention and the third measurement at delivery at stage 1 with the repeated measured ANOVA post hoc LSD showed p-value <0.001. The result showed, there was a significant difference in the mean score of stress before (21.30) and after the second measurement (16.40) and the third measurement (14.64) at delivery after the affirmation intervention. The affirmation class had a lower level of stress at delivery by -7.48 compared to the control group with an effect size of $70.6 \%$.

Table 2. Stress score before and after intervention at four weeks and birth between groups.

\begin{tabular}{|c|c|c|c|c|c|}
\hline & & & \multicolumn{2}{|c|}{} & $\begin{array}{c}\text { ETA } \\
\text { Treatments }\end{array}$ \\
B & $\mathrm{p}$ & Lower & Upper & Square \\
\hline Affirmation & -7.472 & 0.000 & -9.079 & -5.866 & $70.6 \%$ \\
\hline Antenatal & \multicolumn{5}{c}{ Group reference } \\
Education & \multicolumn{5}{c}{}
\end{tabular}

Repeated Measured ANOVA

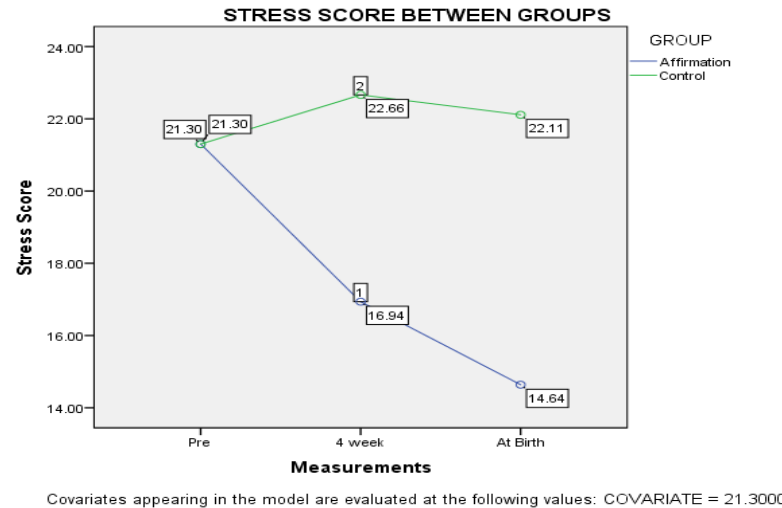

\subsection{Proving The Effect of Positive Affirmation Class on The Anxiety of Pregnant Women During Childbirth}

The results showed that the experimental group who received the affirmation class experienced a sharper decrease in the mean score of anxiety (8.76 ) on the second measurement after 4 weeks of intervention compared to the control group who received the education class. In this study, the control group experienced an increase in the mean score of anxiety (1.33), as well as at the time of the third measurement, the experimental group experienced a decrease (2.90), while the control group experienced a higher mean score of anxiety $(0,34)$.

In the experimental group, different test scores of Anxiety before and after the positive affirmation intervention at the second measurement of the fourth week after the intervention and the third measurement at delivery at stage 1 with the repeated measured ANOVA post hoc LSD showed p-value <0.001. That is, there is a significant difference in the mean score of anxiety before (53.40) and after the second measurement (45.97) 
and the third measurement at delivery (42.98) after the affirmation intervention. The affirmation class got a lower level of anxiety at delivery by 12,092 compared to the control group with an effect size of $62 \%$.

Table 3. Anxiety score before and after intervention at four weeks and birth between groups.

\begin{tabular}{|c|c|c|c|c|c|}
\hline Treatments & B & $\mathrm{p}$ & Lower & Upper & ETA Square \\
\hline Affirmation & -12.092 & 0.000 & -15.244 & -8.8940 & $62.6 \%$ \\
\hline Antenatal Education & \multicolumn{5}{|c|}{ Group reference } \\
\hline
\end{tabular}

\subsection{Discussion}

The results of this study indicate that the intervention group showed a higher mean reduction of stress than the control group that was not given positive affirmation treatment. Although the condition of pregnancy causes many physical and psychological changes, this is due to hormonal changes in pregnant women. Psychological changes are felt, such as worry about changes in body shape, worry about the fetus born in an abnormal condition, causing emotional sensations, fear, anxiety, or stress. Besides, internal and external family support can cause pregnant women to be overly anxious, worry about fear without cause and stress so that they endanger both the mother and the fetus, especially the trimester three pregnancies can be called a waiting phase and are full of vigilance because the mother and family are expecting the baby [29]. These stressful conditions can be overcome through classes for pregnant women plus affirmations with abdominal breathing.

Mother class plus positive affirmations with abdominal breathing teaches abdominal breathing as a form of care by taking deep breaths and exhaling slowly when the mother makes positive affirmations. Abdominal breathing maximizes the oxygen entering the lungs and maximizes the dirty air and toxins out of the lungs. When breathing deeply and regularly, the breathing will turn slower so that the pulse and heart rate also decreases [23]. Besides, abdominal breathing can increase gas exchange, increase ventilation of the alveoli, reduce stress both physically and emotionally which can help reduce pain and anxiety [25]. This means that the breath relaxation technique given can maximize oxygen entry to the lungs, making breathing slower and reducing stress in pregnant women. Breathing can help pregnant women to focus more on managing their thoughts (self-control), emotions and situations at hand. When thoughts, emotions, and situations can be controlled properly, positive energy can appear, and vice versa if it cannot be controlled, negative emotions will arise.

In addition to abdominal breathing techniques, researchers also gave positive affirmations to pregnant women. The literature explains that positive affirmations can affect the universe, when the word for the word comes out in the form of sound, will emit waves into the universe, word waves penetrate the air, and become real. Each syllable used has its energy. When you say "I am healthy" then the universe will give you the ability to do that. Affirmations can affect the subconscious mind and give suggestions to yourself [29]. Positive affirmative sentences such as "My pregnancy is healthy", "Strong amniotic membrane", "Placenta is healthy", "Labor is smooth", "Every time I feel a wave of love, I always smile" and so on, with the aim of convincing and giving positive energy to pregnant women to reduce worry or stress. Self-affirmation is effective against levels of anxiety that can cause stress in the mother, positive thoughts can increase blood flow so that stress can be reduced [30].

This study shows that abdominal breathing techniques and positive affirmations by love card are important for pregnant women to prevent stress and anxiety that can adversely affect both the mother and the fetus. The results of this study can provide class development for pregnant women. Furthermore positive affirmation with abdominal breathing helped the mother relax during pregnancy so that it could significantly help reduce anxiety and stress levels in pregnant women as indicated by decreased blood pressure, pulse, and cortisol levels [31]. The abdominal breathing technique is one of the relaxation techniques that pregnant women can do.

Furthermore, positive affirmation with abdominal breathing can improve the parasympathetic work system, provide a calming effect, and stimulate the release of oxytocin, 
thereby reducing cortisol. This intervention will ultimately improve the well-being of the mother and the fetus so that they are physically and mentally prepared, the breathing improves memory, overcomes eye disorders, eliminates insomnia, eases pent-up thoughts and emotions, and reduces stress, anxiety, and depression levels [32].

Pregnant women class plus positive affirmation by love card with abdominal breathing provides strengthening or affirming yourself to get rid of negative beliefs that exist in the subconscious mind [14]. Positive affirmations prepared for pregnant women have messages on physical and mental health, which play a role in motivating, inspiring, providing support, changing perspectives, influencing the body, soul, and mind to become habits of daily behavior [16]. So that Positive affirmations affect regulating limbic system activity by producing opioids, serotonin, and GABA in the amygdala so that it improves cortisol regulation so that in pregnancy and childbirth it can reduce pain, anxiety, and a more comfortable feeling. Giving positive affirmations plays an important role during pregnancy and childbirth because relaxation and positive affirmations can affirm, give positive opinions, truly acknowledge, and make a positive pregnancy [29]. Non-pharmacological therapy, namely affirmations, affirmations are used as affirmations and reinforcement and reprogramming the subconscious mind and removing false beliefs and beliefs in the subconscious mind. The subconscious mind influences the conscious mind in action. Repeated affirmations can work miracles.

\subsection{Conclusion}

The affirmation class was proven to reduce maternal stress levels at delivery more significantly than the education class, thus the level of anxiety in mothers with positive affirmations decreased significantly more sharply than the control group.

\section{AUTHORS' CONTRIBUTIONS}

RR has made substantial contributions to the conception and design, acquisition of data, analysis and interpretations of data. RR has been involved in drafting manuscript and revising. ASN have made conception and design, acquisition of data. All authors read and approved the final manuscript.

\section{ACKNOWLEDGMENTS}

The author would like to thank to all participants and midwives which helped facilitate this study.

\section{REFERENCES}

[1] N. A. Aziz, Margaretha. Strategi coping terhadap kecemasan pada ibu hamil dengan riwayat keguguran di kehamilan sebelumnya, J. Ilm. Psikol. Terap. 5(1) (2017) 200.

[2] I. Puty, A. Wibowo. Pengaruh keikutsertaan senam hamil terhadap kecemasan primigravida trimester ketiga dalam menghadapi persalinan, J. Biometrika dan Kependud. 1(1) (2012) 26-32.

[3] L. Kuswandi. Hypnobirthing: A gentle way to give birth. Pustaka Bunda, 2013

[4] G. Fink. Stress : Concepts definition, history, Ref. Modul. Neurosci. Biobehav. Psychol. 2016 November.

[5] V. Perciavalle, T. M Blandini, P. Fecarotta, A. Buscemi, D.D. Corrado, L. Bertolo, F. Fichera, M. Coco. Role of deep breathing on stress, Neurol. Sci., 38(3) (2017) 451-458.

[6] G. K. Madhavanprabhakaran, M. S. D'Souza, K. S. Nairy. Prevalence of pregnancy anxiety and associated factors. Int. J. Africa Nurs. Sci. 3 (2015) 1-7.

[7] I. Puspasari, I. Nur, T. Ungsianik. Maternal age as a main factor influencing prenatal distress in Indonesian Primigravida \&, Enfermería Clínica, (2019) DOI:

10.1016/j.enfcli.2019.04.039

[8] P. J. Chen, L. Yang, C. C. Chou, C. C. Li, Y. C. Chang, J. J. Liaw. Effects of prenatal yoga on women's stress and immune function across pregnancy: A randomized controlled trial. Complement. Ther. Med. 31 (2017)109117.

[9] K. Corbijn, van Willenswaard et al. Music interventions to reduce stress and anxiety in pregnancy: A systematic review and metaanalysis. BMC Psychiatry. 17(1) (2017) 1-9.

[10] Kasenda, Wungouw, Lolong, Hubungan stres dengan kejadian insomnia pada ibu hamil di Puskesmas Bahu Kota Manado, J. Keperawatan. 5(1) (2017) 1-7.

[11] L. M. Ellman et al. Maternal cortisol during pregnancy and offspring schizophrenia : In fl uence of fetal sex and timing of exposure', Schizophr. Res. 2019

[12] R. Ilmiasih. Pengaruh teknik hypnorbirthing terhadap tingkat kecemasan ibu hamil pada masa persiapan menghadapi persalinan, Research Report, 2014, pp. 93-100.

[13] L. Kuswandi, Keajaiban Hypnobirthing. Jakarta: Pustaka Bunda, 2011.

[14] A. Yuwinten, N. Tajmiati, Nurvita. Pengaruh komunikasi afirmasi terhadap durasi mual muntah ibu hamil trimester I Kecamatan 
Cibereum Kota Tasikmalaya Tahun 2018, J.

Kesehat. Bakti Tunas Husada J. Ilmu Keperawatan 18(2) (2018) 237-248.

[15] E. D. Maruti, M. Wandrati. Pengaruh teknik relaksasi afirmasi terhadap efikasi diri pada pasien kanker yang menjalani memoterapi di SMC RS Telogorejo. J. Ilmu Keperawatan dan Kebidanan, 8(2) (2019) 1-8.

[16] D. Syaras, Y. Yasir, W. Wirman, Komunikasi intrapersonal pasien hypnobirthing di Rumah Sakit Bersalin Annisa Pekanbaru. J. Ris. Komun. 2(1) (2019)13-20.

[17] F. Wijaya, D. A. Rahayu. Positive affirmation on coping mechanism of chronic renal failure patients. 2(1) (2019) 7-12.

[18] I. M. Agustin, S. Handayani. Case Report: Afirmasi positif pada harga diri rendah situasional pasien fraktur femur, J. Ilm. Kesehat. Keperawatan. 13(2) (2017) 94-98.

[19] H. Indonesia, Modul panduan pelatihan basic hypnosis dan hypnobirthing. Jakarta: PT Kristala Permata Nusantara, 2019.

[20] T. Susilowati, N. Pramana, S. F. Muis. Nonpharmacological intervention on anxiety primigravida, J. Ilm. Permas STIKES Kendal, 9(3) (2019) 181-186.

[21] N. Fuada, B. Setyawat. Pelaksanaan kelas ibu hamil di Indonesia. J. Kesehat. Reproduksi (2015) 67-75.

[22] Y. S. Pratiwi, S. Handayani, L. M. Alfarizi, Pengaruh hypnobreastfeeding terhadap produksi ASI. J. Midwifery 1(5) (2017) 4956.

[23] T. T. P. G. Yoga. Modul prenatal gentle yoga. PT Kristala Permata Nusantara, 2018.

[24] Kemenkes RI. Pedoman pelaksanaan kelas ibu hamil Kemenkes RI 2009-2011. Kementrian Kesehatan RI. pp. 1-26, 2014.
[25] F. D. Irawan, N. L. P. E. Sudiwati, N. Dewi, Perbandingan tekhnik relaksasi nafas dalam dan kompres dingin terhadap penurunan tingka nyeri haid (dismenore) pada mahasiswi di asrama sanggau dan ikatan keluarga belu di landungsari kota malang, Nurs. News (Meriden). 1 (2016) pp. 358-368.

[26] M. Mongan. Hypnobirthing: The Mongan method. Deerfield Beach, Florida: Health Communication, Inc, 2015.

[27] Y. A. Ariyani, A. D. Listyarini. Pengaruh terapi bermain flashcard terhadap pengetahuan gizi. Proceeding HEFA. 2017, pp. 449-455.

[28] W. N. Sijangga. Hubungan antara strategi coping dengan kecemasan menghadapi persalinan pada ibu hamil hipertensi, 2010.

[29] N. Cholifah, R. Fahrida, D. Hartinah. Pengaruh pemberian afirmasi positif terhadap perubahan psikologis ibu hamil dengan pre eklampsia di klinik kandungan RSUD RA Kartini Kabupaten Jepara tahun 2017. Indo. J. Perawat. 2(2) (2017) 80-86.

[30] T. Indrayani ,W. Sumarni, Efektivitas afirmasi tenaga kesehatan pada tingkat kecemasan ibu bersalin multipara di rsud bula kabupaten seram bagian timur tahun 2018/2019, J. Ilmu dan Budaya. 41(63) (2019) 7489-7494.

[31] Y. Septianingrum, Efektivitas relaksasi selama kehamilan terhadap penurunan stres, kecemasan ibu hamil dan respon janin dalam kandungan, J. Ilm. Kesehat. 8(2) (2015) 206212.

[32] E. Salafas, R. Anisa, V. I. Rusita, Efektivitas Hypno-EFT dan Pernafasan Yoga dalam Menurunkan Kecemasan Ibu Hamil di BPM Ny. Sri Kustinah, J Publ. Kebidanan Akbid YLPP Purwokerto 7(2) (2016) 84-94. 